\title{
Analisis Literasi Teknologi Informasi Guru Matematika SMK Swasta Jakarta Selatan Ditinjau dari Aspek Manajemen Pendidikan
}

\author{
Huri Suhendri \\ Universitas Indraprasta PGRI \\ huri-suhendri@unindra.ac.id \\ Mailizar \\ Universitas Indraprasta PGRI \\ malizar@unindra.ac.id \\ Rita Ningsih \\ Universitas Indraprasta PGRI \\ rita.ningsih@unindra.ac.id \\ Rita Retnowati \\ Universitas Pakuan \\ ritaretnowati@unpak.ac.id
}

\begin{abstract}
In the era of information technology-based 4.0, all fields use information technology, as well as in the world of education. In learning, the use and use of information technology is very important in supporting the smooth teaching and learning process. So that the ability of teachers in information technology literacy is very important and needs to be developed. This study aims to describe the level of information technology literacy of mathematics teachers in private vocational schools in South Jakarta and identify the factors that influence it. The research method used is descriptive qualitative method. The research sample was 41 mathematics teachers at private vocational schools in South Jakarta, who were taken by purposive sampling technique. Information techniques through questionnaires and interviews. The results showed that the level of information technology literacy for mathematics teachers in private vocational schools in South Jakarta was still low. One of the factors affecting literacy is the lack of training in the use of information.

Keywords: Analysis, information technology literacy, mathematicsteacher, south jakarta, education management aspects
\end{abstract}

Abstrak: Dalam era 4.0 yang berbasis teknologi informasi, semua bidang menggunakan teknologi informasi, demikian pula dalam dunia pendidikan. Dalam pembelajaran, pemanfaatan dan penggunakan teknologi informasi sangat penting dalam menunjang kelancaran proses belajar mengajar. Sehingga kemampuan guru dalam literasi teknologi informasi sangat penting dan perlu dikembangkan. Penelitian ini bertujuan untuk mendeskripsikan tingkat literasi teknologi informasi guru matematika SMK Swasta di Jakarta Selatan dan mengidentifikasi faktor yang mempengaruhinya. Metode penelitian yang digunakan adalah metode kualitatif deskriptif. Sampel penelitiannya adalah guru matematika SMK Swasta di Jakarta Selatan sebanyak 41 orang yang diambil dengan teknik purposive sampling. Teknik pengumpulan data melalui kuisioner dan wawancara. Hasil penelitian menunjukan bahwa tingkat literasi teknologi informasi guru matematika SMK Swasta di Jakarta Selatan masih tergolong rendah. Salah satu faktor yang mempengaruhi literasi teknologi adalah kurangnya pelatihan pemanfaatan teknologi informasi.

Kata Kunci: Analisis, Literasi Teknonologi Informasi, Guru Matematika, Jakarta Selatan, Aspek Manajemen Pendidikan 


\section{PENDAHULUAN}

Pendidikan dalam abad ke-21 atau era 4.0 berbasis teknologi informasi, sehingga menuntut guru memiliki kemampuan dalam teknologi informasi yang baik. Selain itu, daya dukung dari pihak sekolah pun harus baik dalam rangka menunjang pendidikan khususnya pembelajaran yang berbasis teknologi baik media pembelajarannya maupun sumber belajarnya. Hal ini sesuai pendapat Helaludin (2019:53) bahwa dalam menyongsong abad ke-21, kehadiran teknologi informasi dankomunikasi (TIK) dalam bidang pendidikan memang tidak dapat dielakkan lagi.Hampir seluruh elemen pendidikan dan pembelajaran dilakukan dengan menerapkan TIK di dalamnya. Kondisi inilah yang menuntut para pendidik dan peserta didik untuk melek teknologi. Sehingga penguasaan teknologi informasi baik oleh guru maupun siswa sangat penting dalam menunjang proses belajar mengajar.

Namun masih banyak guru tidak memiliki keterampilan dalam teknologi informasi yang diperlukan dan mereka juga tidak memiliki pelatihan khusus yang diperlukan untuk dapat menggunakan sumber belajar dan media pembelajaran yang berbasis teknologi informasi. Gogot Suharwoto (dalam Fathurrohman, 2020) mengatakan saat ini teknologi masih sulit masuk di ruang-ruang kelas, disebabkan masih banyaknya guru-guru yang gagap teknologi (gaptek). Kompetensi TIK jumlah guru yang akrab dengan teknologi tak sampai 50 persen dari total guru yang ada. Itu terlihat dari pemetaan yang teranyar. Pemetaan tersebut mengadopsi sistem yang diterapkan United Nations Educational, Scientific and Cultural Organization (UNESCO). Yakni ada empat level, level satu ICT literasi, atau literasi Teknologi, Informasi, Komunikasi. Kedua, level ketika guru mampu mengoperasikan dan mengaplikasikannya dengan mudah. Level ketiga adalah level ketika guru sudah bisa membuat konten sendiri. Level keempat, guru sudah mampu menjadi trainer. Dari hasil pemetaan pihak Kemendikbud dari 28 ribu (guru) ternyata yang menguasai level 1 baru yang lolos 46\%.Jadi memang kendala utama kompetensi menguasai masih di bawah 50\%. Sementara untuk level kedua baru 14\% yang bisa lolos. Berdasarkan pernyataan tersebut dapat digambarkan bahwa tingkat literasi teknologi informasi guru di Indonesia masih rendah dan masih dalam level satu yaitu pemahaman tentang literasi teknologi informasi.

Sehingga guru harus meningkatkan diri dalam penguasaan teknologi informasi. Penggunakan teknologi dalam pembelajaran, guru membutuhkan dukungan khususnya dari institusi sekolahnya. Satuan pendidikan atau sekolah harus mampu untuk menyiapkan hal-hal terkait dengan tantangan dan peluang era 4.0 khususnya dalam kemapuan teknologi informasi. Struktur tuntutan era 4.0 adalah: (1) literasi dasar; (2) literasi digital; (3) literasi teknologi; dan (4) literasi manusia (Aoun, 2017); (5) literasi budaya ekonomi-sosial; (6) karir \& 
kecakapan hidup; (7) kepemimpinan dan tanggung jawab (Triling \& Fadell dalam Astini, 2019:114). Selanjutnya Astini (2019:114) menyatakan bahwa tantangan dan peluang era 4.0 harus digunakan oleh satuan pendidikan untuk mulai menyesuaikan dengan berbagai perubahan, agar siap melayani para peserta didik yang berasal dari generasi milenial dari sisi pedagogi, digital skills, literasi dasar, literasi teknologi, literasi manusia, penguatan pendidikan karakter dan kecakapan hidup.

Perkembangan teknologi akan mempengaruhi kelangsungan dalam pembelajaran di sekolah, baik guru maupun siswanya dalam pembelajaran. Menurut Suhendi, dkk. (2017:2), "perkembangan teknologi akan berpengaruh terhadap kelangsungan proses pembelajaran di Sekolah, nampaknya Penggunaan Teknologi merupakan kebutuhan primer dalam dunia pendidikan, baik peserta didik maupun guru pada umumnya dapat menggunakan teknologi sesuai dengan perkembangannya". Hal ini menunjukkan bahwa teknologi adalah faktor pendukung suksesnya proses pembelajaran di sekolah. Hal tersebut juga senada dengan pendapat Muhdi (dalam Insetyonoto, 2020) bahwa guru dituntut dapat memanfaatkan Information and Communication Technology (ICT) atau Teknologi Informasi dan Komunikasi (TIK). Guru diharapkan dapat akrab dengan berbagai aplikasi, coding, dan literasi teknologi dalam membaca data sehingga dapat diterapkan dalam pembelajaran. Senada dengan hal tersebut, Latip (2020:108) menyatakan bahwa literasi teknologi, informasi, dan komunikasi (TIK) menjadi faktor penting dalam pembelajaran jarak jauh selama masa pandemi Covid-19. Penggunaan teknologi informasi dalam pendidikan khususnya pembelajaran sangat penting dan perlu dikembangkan agar lebih maksimal.

Penggunaan teknologi informasi dalam pembelajaran di sekolah dipengaruhi oleh karakteristik guru, sekolah dan sistem pendidikan. Hal ini seperti yang telah dinyatakan oleh Taimalu \& Luik (dalam Ifinedo, dkk, 2019:4) bahwa "Research over decades has shown that technology integration in the classroom depends on several connected factors relating to teachers' characteristics, schools, and educational systems". Artinya penerapan teknologi informasi dalam pembelajaran di kelas termasuk dalam pembelajaran matematika dipengaruhi oleh karakteristik guru, sekolah, dan sistem pendidikan.Penerapan teknologi informasi di setiap sekolah akan berbeda tergantung dari kualitas guru, daya dukung sarana dan prasarana sekolah termasuk kebijakan sekolah, dan sistem pendidikan yang ditetapkan oleh pemerintah pusat maupun daerah.

Selain karakteristik guru, tingkat literasi teknologi informasi dipengaruhi oleh faktor lain yaitu penerapan supervisi klinis dari kepala sekolah. Hal ini sesuai penelitian Yulianti (2019:106) bahwa penggunaan model supervisi klinis meningkatkan kemampuan guru dalam membuat dan menyebarkan soal 
menggunakan aplikasi teknologi yaitu aplikasi Kahoot. Proses bimbingan dan arahan selama proses pembinaan yang dilakukan sudah diupayakan intensif. Sehingga guru tidak mengalami kesulitan dalam melaksanakan proses pembinaan dalam membuat dan menyebarkan soal menggunakan aplikasi kahoot. Artinya pembinaan langsung dari kepala sekolah secara rutin dan kontinu juga dapat berperan dalam peningkatan literasi teknologi informasi guru matematika. Demikian pula penelitian Saparudin (2018) bahwa penggunaan model KILAT meningkatkan kemampuan guru dalam membuat dan menyebarkan soal menggunakan aplikasi teknologi yaitu aplikasi Kahoot.

Permasalahan rendahnya literasi teknologi terjadi pula pada guru-guru matematika SMK Swasta di Kota Jakarta Selatan. Berdasarkan uraian-uraian tersebut, peneliti tertarik untuk melakukan suatu kajian dalam penelitian dengan judul Analisis literasi teknologi informasi guru matematika SMK swasta Jakarta Selatan ditinjau dari aspek manajemen pendidikan. Permasalahan yang akan dikaji yaitu tingkat literasi teknologi informasi dan faktor yang mempengaruhi literasi teknologi informasi guru matematika SMK Swasta di Jakarta Selatan tahun pelajaran 2020/2021.

\section{METODE PENELITIAN}

Penelitian dilakukan dari bulan Agustus sampai Oktober 2020 di SMK swasta kota Jakarta Selatan, DKI Jakarta. Penelitian ini menggunakan pendekatan kualitatif dengan metode deskriptif. Menurut Nassaji (2015:129), "The goal of descriptive research is to describe a phenomenon and its characteristics. This research is more concerned with what rather than how or why something has happened." Artinya tujuan penelitian deskriptif adalah mendeskripsikan suatu fenomena dan karakteristiknya. Penelitian ini lebih mementingkan apa daripada bagaimana atau mengapa sesuatu dimiliki terjadi. Sampel penelitian ini sebanyak 41 orang guru matematika SMK swasta di kota jakarta selatan yang diambil dengan teknik purposive sampling. Sampel penelitian tersebut dilibatkan sebagai sumber data primer tentang literasi teknologi informasi. Teknik pengumpulan data yang digunakan yaitu kuisioner dan wawancara. Instrumen penelitian terdiri dari: kuisioner sebanyak 10 butir penyataan dan pedoman wawancara. Teknis analisa data terdiri dari reduksi data, penyajian data, dan penarikan kesimpulan.

\section{HASIL DAN PEMBAHASAN}

Pengumpulan data penelitian dilakukan pada tanggal 7-13 September 2020 melalui penyebaran kuisioner melalui google form kepada guru matematika SMK swasta di kota Jakarta Selatan. Kemudian tahapan dalam analisis data penelitian kualiatitif terdiri dari: 


\section{Reduksi Data}

Dari 41 responden, hanya 37 yang memenuhi syarat untuk dilanjutkan sebagai data penelitian yang akan diolah dan dianalisis. Syarat responden yang digunakan oleh peneliti adalah memliki perangkat komputer: PC, laptop/ notebook, atau netbook.

\section{Penyajian Data}

Karakteristik responden dalam penelitian ini digambarkan berdasarkan wilayah (kecamatan) guru dalam melaksanakan tugasnya sehari-hari dan kualifikasi pendidikan (jenjang pendidikan) guru matematika.Karakteristika responden berdasarkan wilayah (kecamatan) guru dalam melaksanakan tugasnya sehari-hari, seperti pada tabel berikut ini:

Tabel 1.

Data Responden Berdasarkan Wilayah

\begin{tabular}{clc}
\hline No. & \multicolumn{1}{c}{ Wilayah (Kecamatan) } & Jumlah Responden \\
\hline 1 & Cilandak & 1 \\
\hline 2 & Pasar Minggu & 3 \\
\hline 3 & Jagakarsa & 4 \\
\hline 4 & Kebayoran Lama & 8 \\
\hline 5 & Pesanggrahan & 16 \\
\hline 6 & Mampang Prapatan & 2 \\
\hline 7 & Pancoran & 2 \\
\hline 8 & Setiabudi & 1 \\
\hline & & $\mathbf{3 7}$ \\
\hline
\end{tabular}

Berdasarkan tabel 1 di atas, terlihat bahwa sebaran wilayah (kecamatan) berasal dari 8 kecamatan, sedangkan di kota Jakarta Selatan terdapat 10 kecamatan. Hal ini ini menunjukkan bahwa dari sebaran wilayah (kecamatan) sudah memenuhi syarat untuk pengumpulan data. Kemudian berdasarkan kualifikasi pendidikan guru, sebaran data responden seperti pada tabel di bawah ini:

Tabel 2.

Data Responden Berdasarkan Kualifikasi Pendidikan

\begin{tabular}{clc}
\hline No. & \multicolumn{1}{c}{ Pendidikan } & Jumlah \\
\hline 1 & S1 Pesponden \\
\hline 2 & S1 Matematikan Matematika & 22 \\
\hline 3 & S1 Jurusan Lain & 6 \\
\hline 4 & S2 Pendidikan Matematika & 5 \\
\hline \multicolumn{2}{c}{ Jumlah } & 4 \\
\hline
\end{tabular}


Berdasarkan tabel 2 di atas, kualifikasi guru matematika SMK swasta di Jakarta Selatan lulusan S1 Pendidikan Matematika sebanyak 22 orang (59,5\%), lulusan S1 Matematika berjumlah 6 orang (16,2\%), S1 Jurusan lain 5 orang (13,5\%), dan S2 Jurusan Pendidikan Matematika 4 orang (10,8\%).

Kemudian berdasarkan hasil kuisioner tentang kemampuan literasi teknologi informasi didapat data sebagai berikut:

a. Software pembelajaran matematika yang dikuasai.

Diantara beberapa software pembelajaran yang ada (maple, geogebra, mathlab, adobe flash, atau macromedia flash) sebanyak 51,4\% guru tidak menguasaidan 48,6\% guru menguasai.

b. Penggunakan perangkat komputer dalam pembelajaran matematika.

Dalam pembelajaran matematika sebanyak $24,3 \%$ guru selalu menggunakanperangkat komputer (PC, laptop/ notebook, atau netbook) sebanyak 32,4\% sering menggunakan; 35,1\% kadang-kadang menggunakan; 2,8\% jarang menggunakan; dan 5,4\% tidak pernah menggunakan.

c. Jenis media pembelajaran yang sering digunakan.

Media pembelajaran yang digunakan dalam mengajar matematika: sebanyak 48,6\% guru menggunakan benda konkrit (benda yang ada disekitar); 8,6\% guru menggunakan alat peraga manual; dan 42,9\% menggunakan software atau aplikasi komputer.

d. Sumber belajar atau bahan ajar.

Bahan ajar matematika yang sering digunakan guru yaitu 72,2\% menggunakan bahan ajar (buku, diktat, modul, atau LKS) dari Kemdikbud atau penerbit; 13,9\% bahan ajar (buku, diktat, modul, atau LKS) karya sendiri; dan 13,9\% menggunakan internet.

e. Jumlah media pembelajaran berbasis komputer(software atau aplikasi).

Data guru yang membuat media pembelajaran berbasis komputer (software atau aplikasi) dalam 1 semester dengan jumlah lebih dari 4 produk sebanyak $11,8 \%$; guru yang membuat 4 produk sebanyak $11,8 \%$; membuat 3 produk sebanyak 2,8\%; membuat 2 produk sebanyak $11,8 \%$; membuat 1 produk sebanyak 32,4\%; dan tidak membuat produk sebanyak $29,4 \%$.

Dari data hasil kuisioner literasi teknologi informasi diperoleh bahwa sebagian besar guru matematika SMK swasta di kota Jakarta Selatan memiliki literasi teknologi informasi yang masih rendah. Sehingga perlu dilakukan upaya perbaikan atau peningkatan literasi teknologi informasi bagi guru matematika tersebut. Berdasarkan wawancara dengan guru yang menjadi responden bahwa kemampuan tentang teknologi informasi yang dimiliki guru sebagian besar diperoleh melalui pelatihan komputer dari sekolah maupun pihak lain. 


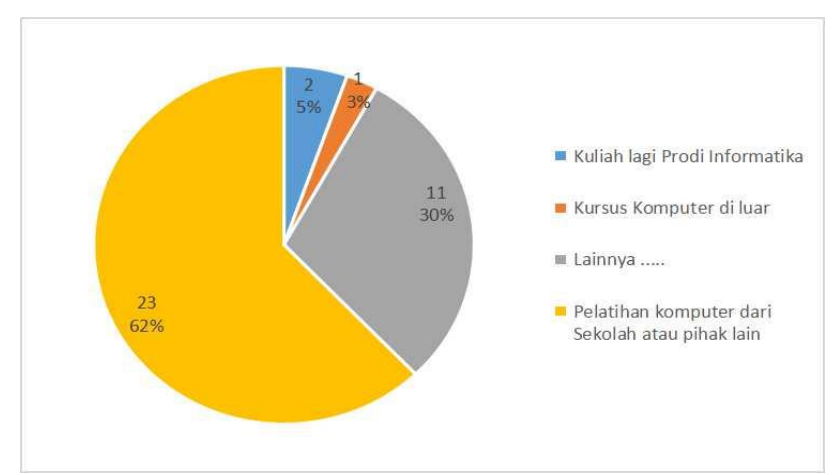

Gambar 1. Cara Meningkatkan Literasi Teknologi

Pihak manajemen sekolah perlu membuat program pelatihan komputer secara rutin dengan menerapakan aspek manajemen pendidikan agar literasi teknologi informasi guru matematika dapat meningkat. Sehingga kualitas pendidikan di sekolah tersebut akan meningkat sejalan dengan meningkatnya literasi teknologi guru matematika.

\section{Penarikan Kesimpulan}

Berdasarkan data hasil penelitian di atas, terlihat bahwa literasi teknologi informasi guru matematika SMK swasta di kota Jakarta Selatan tergolong rendah. Hal tersebut terlihat dari 5 komponen yang ditanyakan peneliti kepada responden semuanya masih di bawah 50\%. Salah satu upaya yang dapat dilakukan untuk meningkatkan literasi teknologi guru matematika melalui pelatihan komputer baik yang dilaksanakan oleh sekolah maupun pihak lain dengan menerapkan aspek manajemen pendidikan.

Literasi teknologi informasi merupakan suatu kemampuan yang harus dimiliki oleh setiap orang termasuk guru matematika dalam era digital atau revolusi industri 4.0. Demikian pula bagi guru matematika SMK swasta di kota Jakarta Selatan, dimana lulusan SMK dipersiapkan untuk menjadi tenaga kerja operasional yang siap pakai. Sehingga guru matematika SMK swasta di kota Jakarta selatan harus mampu mentransfer materi pelajaran matematika kepada siswa dalam bentuk contoh konkrit sesuai keahlian jurusan siswa. Selain itu, dalam masa pandemi covid-19 pembelajaran lebih fokus dilaksanakan secara daring yang membutuhkan media perangkat komputer dan teknologi informasi. Hal ini sependapat dengan Saman, dkk. (2019:79) bahwa indikator literasi informasi dapat mendukung pembelajaran yang dilaksanakan di kelas dan dapat direkomandasikan ke dalam kurikulum reguler pada berbagai otoritas pengajaran. Indikator literasi informasi relatif bebas dan generik, oleh karenanya dapat dikembangkan dan disesuaikan untuk dapat mengukur literasi Teknologi Informasi dan Komunikasi. 
Hasil penelitian yang dilakukan oleh peneliti dengan pengumpulan data melalui kuisioner tentang literasi teknologi informasi diperoleh data yaitu lebih dai 50\% literasi teknologi informasi guru matematika SMK swasta di Jakarta Selatan masih rendah. Hal ini tergambarkan dari jumlah guru yang mengusai software pembelajaran matematika yaitu sebesar $48,6 \%$ dansebesar $51,4 \%$ tidak menguasai software pembelajaran matematika. Dari aspek ini terlihat bahwa kemampuan guru dalam pengusaan aplikasi atau software pembelajaran matematika masih tergolong rendah. Padahal pengusaan teknologi dalam bentuk software atau aplikasi baru yang berkaitan dengan pembelajaran khususunya pembelajaran matematika sangat penting. Zainurrisalah, dkk. (2018:132) menyatakan bahwa literasi teknologi adalah kemampuan dalam menggunakan teknologi baru, memahami bagaimana teknologi baru dikembangkan dan memiliki kemampuan untuk menganalisis bagaimana pengaruh teknologi dalam kehidupan. Penguasaan guru dalam penerapan teknologi informasi khususnya software pembelajaran dalam pelajaran matematika perlu dikembangkan.

Kemampuan atau literasi teknologi informasi tergambar pula dari pengunaan perangkat komputer dalam kegiatan pembelajaran khususnya pembelajaran matematika. Berdasarkan hasil penelitian diperoleh data dalam hal penggunakan perangkat komputer dalam pembelajaran matematika ada sebanyak 24,3\% guru selalu menggunakanperangkat komputer (PC, laptop), $32,4 \%$ sering menggunakan; 35,1\% kadang-kadang menggunakan; $2,8 \%$ jarang menggunakan; dan 5,4\% tidak pernah menggunakan.Hal ini menunjukkan bahwa guru matematika yang selalu dan sering menggunakan perangkat komputer baik PC maupun laptop masing sekitar 56,7\% atau masing tergolong sedang. Setyawan (2018) menyatakan bahwa literasi teknologi adalah kemampuan seseorang untuk bekerja secara independen maupun bekerjasama dengan orang lain secara efektif, penuh tanggung jawab dan tepat dengan menggunakan instrumen teknologi untuk mendapat, mengelola, kemudian mengintegrasikan, mengevaluasi, membuat serta mengkomunikasikan informasi. Penggunaan teknologi informasi dalam kegiatan rutin guru matematika baik dalam mengajar maupun administrasi pendidikan guru harus dikembangkan lagi.

Dalam penggunaan media pembelajaran, guru matematika SMK swasta di kota Jakarta Selatan masih minim dalam penggunakaan sofware atau aplikasi komputer sebagai media pembelajaran. Berdasarkan hasil penelitian diperoleh data bahwa jenis media pembelajaran yang digunakan dalam mengajar matematika yaitu sebanyak 48,6\% guru menggunakan benda konkrit (benda yang ada disekitar); 8,6\% guru menggunakan alat peraga manual; dan 42,9\% menggunakan software atau aplikasi komputer. Padahal dalam era revolusi industri 4.0 menekankan dalam penggunakan teknologi informasi dalam segala bidang termasuk dalam pembelajaran. Selain itu, dalam masa pandemi covid-19 yang menerapkan pembelajaran secara daring atau jarak jauh memerlukan media 
pembelajaran berbasis teknologi informasi dalam menunjang pelaksaaan pembelajarannya. Menurut Aminy (2015:929) bahwa teknologi internet merupakan jenis media e-Education yang dapat menciptakan interaksi dua arah secara online. Media ini digunakan untuk mengembangkan proses belajar mengajar. Penggunaan teknologi informasi sebagai media pembelajaran harus lebih dikembangkan lagi.

Kemudian penggunaan sumber belajar dari internet juga sangat penting dalam pembelajaran matematika saat ini. Dengan kemajuan teknologi informasi dan kondisi pandemi covid-19, guru harus mampu memberikan informasi tentang sumber belajar dari internet. Berdasarkan hasil penelitian didapat data bahwa sumber belajar atau bahan ajar yang sering digunakan oleh guru dalam mengajar matematika lebih banyak menggunakan referensi dalam bentuk cetak baik berupa buku, diktat, modul, atau LKS yang diberikan oleh Kemdikbud, penerbit; atau pun karya sendiri;sedangkan hanya 13,9\% menggunakan internet. Hal ini menunjukkan bahwa penggunaan internet sebagai sumber belajar oleh guru matematika SMK swasta di kota Jakarta Selatan masih sangat rendah yaitu sebesar $13,9 \%$. Padahal internet dapat dijadikan sumber belajar yang lebih luas jika dibandingkan dengan sumber belajar hanya dari buku cetak. Aminy (2015: 929) menyatakan bahwa internet dikategorikan sebagai sumber belajar yang mampu menyalurkan berbagai informasi yang berbetuk ilmiah maupun non ilmiah pada mahasiswa dimana saja maupun kapan saja tanpa mengira batas ruang dan waktu. Artinya internet sebagai sumber belajar dan secara tidak langsung membantu peserta didik baik siswa maupun mahasiswa dalam proses pembelajaran.

Literasi teknologi juga ditinjau dari pembuatan media pembelajaran matematika berbasis komputer (software atau aplikasi), dalam waktu 1 semester hanya ada 26,4\% guru yang membuat media pembelajaran lebih dari 2 produk; $32,4 \%$ guru hanya membuat 1 produk; dan 29,4 \% guru tidak membuat produk sama sekali. Hal ini menunjukkan kemampuan guru matematika SMK swasta di kota Jakarta Selatan dalam membuat media pembelajaran berbasis komputer masih rendah. Padahal saat ini di Indonesia sudah mulai memasuki era revolusi industri 4.0 dimana digitalisasi telah diterapkan pada seluruh aspek kehidupan masyarakat sehari-hari, termasuk dalam dunia pendidikan.

Berdasarkan uraian-uraian tersebut di atas, hal tersebut menunjukkan secara umum literasi teknologi guru matematika SMK swasta di kota Jakarta Selatan masih tergolong rendah. Sehingga perlu dilakukan upaya untuk mengatasi permasalahan dalam hal rendahnya literasi teknologi guru matematika tersebut. Salah satu upayanya melalui membekali calon-calon guru di LPTK dengan kemampuan penguasaan komputer dan teknologi informasi. Hal ini sejalan dengan Nasution (2018:17) bahwa, "perguruan tinggi yang menyiapkan calon guru matematika diharapkan menyediakan matakuliah-matakuliah untuk 
mengembangkan keterampilan mahasiswa calon guru matematika terkait bagaimana mendesain pembelajaran dengan memanfaatkan teknologi, keterampilan penguasaan dan penggunaan software matematika dalam pembelajaran, penguasaan ICT serta keterampilan mendesain pembelajaran secara online". Peranan perguruan tinggi khususnya LPTK (Lembaga Pendidikan Tenaga Kependidikan) sangat penting terkait dalam menyiapkan lulusan calon guru yang mampu menguasai teknologi informasi dan komunikasi.

Selain upaya tersebut di atas, upaya yang lain dengan pembekalan kemampuan penguasaan dan penggunaan teknologi informasi guru melalui pelatihan atau workshop teknologi informasi. Hal ini sesuai dengan hasil wawancara dengan guru matematika SMK swasta kota Jakarta Selatan bahwa sekitar 62\% menginginkan adanya pelatihan komputer baik oleh pihak sekolah maupun pihak lain dan biaya tidak dibebankan kepada guru. Hal ini sejalan dengan pendapat Alt (2018:49), "With the growing attention paid to lifelong learning skills, teachers should be encouraged to participate in programs such as online learning communities. Ongoing interactions might enrich their knowledge and skills obtained through periodic training programs. Through such communities and practice platforms, they can exchange information, converse through an online threaded discussion forum as well as within small and large group face-to-face meetings as part of their ICT professional development activities. Dalam rangka melaksanakan solusi tersebut perlu menerapkan aspek manajemen pendidikan agar upaya tersebut berhasil mencapai tujuan. Penerapan aspek manajemen pendidikan tersebut mulai dari tahap perencanaan yaitu mempersiapkan kegiatan pelatihan dan materi yang akan disampaikan kepada para guru serta persyaratan guru yang akan diikutsertakan dalam pelatihan tersebut. Kemudian tahap pengorganisasian yaitu menentukan narasumber yang akan menyampaikan materi dan juga peserta yang layak mengikuti pelatihan sesuai dengan persyaratan yang telah dibuat. Terakhir tahap pelaksanaan yaitumelaksanakan kegiatan pelatihan sesuai dengan rencana. Terakhir tahap monitoring dan evaluasi yaitu memantau jalannya kegiatan pelatihan, mengukur efektifitas pelatihan dalam mencapai tujuan sesuai dengan rencana.

\section{KESIMPULAN}

Berdasarkan hasil penelitian dan pembahasan, maka dapat disimpulkan bahwa literasi teknologi informasi guru matematika SMK swasta di Kota Jakarta Selatan tergolong rendah. Selain itu, faktor-faktor yang mempengaruhinya adalah kemampuan guru dalam pengunaan komputer dan pengalaman dalam mengikuti pelatihan komputer. Solusi untuk mengatasi rendahnya literasi teknologi informasi guru matematika tersebut melalui pelatihan komputer dan perencaannya (action plan) dengan menerapkan aspek manajemen pendidikan yaitu perencanaan, pengorganisasian, pelaksanaan, dan pengawasan. 


\section{REFERENSI}

Alt, D. (2018).Science teachers' conceptions of teaching and learning, ICT effificacy, ICT professional development and ICT practices enacted in their classrooms. Teaching and Teacher Education, 73, 141-150.

Aminy, M.Z. (2015).Pemanfaatan Media Internet sebagai Sumber Belajar Mahasiswa Program Studi Pendidikan Matematika di STKIP Bima. Jurnal KIP, IV(2), 927-932.

Astini, N.K.S. (2019). Pentingnya Literasi Teknologi Informasi dan Komunikasi bagi Guru Sekolah Dasar untuk Menyiapkan Generasi Milenial. Prosiding Seminar Nasional Dharma Acarya ke-1, ISBN 978-602-53984$1-4$.

Fathurrohman.(2020). Kompetensi Guru pada Teknologi Masih Rendah.https:/ fin.co.id/2020/02/07/kompetensi-guru-pada-teknologimasih-rendah/.

Helaludin.(2019). Peningkatan Kemampuan Literasi Teknologi dalamUpaya Mengembangkan Inovasi Pendidikandi Perguruan Tinggi. Jurnal Pendais, 1(1), 44-55.

Ifinedo, E., Rikala, J.,\& Hamalainen, T. (2019). Factors affecting Nigerian teacher educators' technology integration: Considering characteristics, knowledge constructs, ICT practices and beliefs. Computer and Education, 2-56.

Insetyonoto. (2020). Guru harus Melek Literasi Teknologi Pembelajaran. https://www.gatra.com/detail/news/484282/milenial/guru-harusmelek-literasi-teknologi-pembelajaran.

List, A., Brante, E.W.,\& Klee, H.L. (2020). A framework of pre-service teachers' conceptions about digital literacy: Comparing the United States and Sweden. Computers and Education, 148, 1-20.

Nasution, S.H. (2018). Pentingnya Literasi Teknologi bagi Mahasiswa Calon Guru Matematika. JKPM (Jurnal Kajian Pembelajaran Matematika), 2(1), 14-18.

Saman, M.I., Koeshandayanto, S., Sunaryono, Razak, A., dan Rosdiana. (2019). Eksplorasi Literasi Teknologi Informasi dan Komunikasi Siswa melalui Blended Learning Fisika. Jurnal Pendidikan, 4(1), 79-84.

Saparudin, Y. (2018). Upaya Meningkatkan Kemampuan Literasi Teknologi Guru SMA melalui Supervisi Akademik Kreatif. Prosiding Internation al Conference on Education and Regional Development 3rd (ICERD) UPI, 1-14. ISBN :978-602-425-337-0. 
302 | Tadbir: Jurnal Studi Manajemen Pendidikan, Vol. 4, No. 2, 2020

Setyawan, I.A. (2018). Kupas Tuntas Jenis dan Pengertian Literasi. Online: gurudigital.id.

Suhendi, HN., Wahidah, SK., Linda, dan Novita, Y. (2017). Profil Kemampuan Literasi teknologi Peserta Didik SMA di Kota Bandung. JoTaLP : Journal of Teaching and Learning Physics, 2(2), 01-06.

Yulianti, R.Y. (2019). Model Kepengawan Sekolah untuk Meningkatkan Literasi Teknologi Guru SMPN 43 Bandung. Syntax Literate, 4(2), 99-109.

Zainurrisalah, T.F., Suwarma, I.F., dan Jauhari, A. (2018). Mengukur Kemampuan Literasi Teknologi dan Rekayasa (Engineering) Melalui Penerapan Pembelajaran STEM dalam Fisika. Prosiding Seminar Nasional Fisika (SINAFI) UPI, 131-135. ISBN: 978-602-74598-2-3. 